i rzeczownikowe. "Fidelis", jako przymiotnik znaczy "wierny", odnosi się do abstraktu, określa duszę człowieka i jej pobożność. "Fidelis" odnosi się jednak również do konkretu, określa wtedy człowieka 1 znaczy: "wierny" / konotacja religijna/; "wierzacy", "nawrócony", "taki, który przyją chrzest"/konotacja religijna/; "godny zaufania", "rzetelny" /konotacja raczej świecka, etyczna, uogólniająca/. Wyraz "fidelis" w uzyciu rzeczownikowym znaczy: "chrześcijanin", "wierny wyznawca Chrystuśa".

Całość pracy zamyka "Zakończenie", które w rekapitulacji nawiązuje do wyników badań prowadzonych w latach 60-tych w Sekcji Filologii Klasycznej KUL, dotyczących znaczenia wyrazów "fides" i "fidelis" u św. Cypriana, św. Hilarego i Laktancjusza.

Ks. Henryk Wójtowicz - Lublin

\title{
9. Elżbieta Krych, Symplicjusz. Listy. Wstęp - przekład - komentarz, Lublin 1986, maszynopis, s. XXIV + 60。
}

Jest to praca magisterska napisana w Sekcji Filologii Klasycznej KUL pod kierunkiem ks. doc. dra hab. H. Wójtowicza, zawierająca wstęp, przekład wszystkich 21 listów papieża Symplicjusza /468-483/, komentarz, indeks osobowy $i$ bibliografie. Jest to pierwsze polsce tłumaczenie listów Symplicjusza/Simplicius/, powstałe z okazji 1500 rocznicy śmierci tego papieza. Główny trzon listów, to pisma skierowane do patriarchy konstantynopolitańskiego Akacjusza /471$489 /$ - jest ich 10 - oraz 4 listy adresowane do cesarza Wschodu Zenona /474-491/.

Listy te stanowią ciekawą dokumentację z czasów kształtowania się $i$ umacniania władzy papieskiej, przy jednoczesnym upadku władzy cesarskiej na Zachodzie. Symplicjusz zajmuje się w nich sprawa prawidłowej elekcji i konsekracji biskupów, a także troszczy się o przestrzeganie uchwał Soboru Chalcedońskiego /451/; z jednej strony usiłuje,osłabić wpływy wyznawców monofizytyzmu na Wschodzie, z drugiej zaś wzmocnić pozycję biskupów ortodoksyjnych. Jest to niewątpliwie interesująca pozycja dla badaczy prawa kanonicznego, historyków, Pilologów, a zwłaszcza dla zajgujących się przyczynami powstania pierwszej schizmy na Wschodzie, jaka była 
schizma akacjańska /484-518/ oraz ciekawe cródło historyczne z czasów, kiedy kolíczyła się epoka starożytności, a zaczynało średniowi ecze.

\section{Piotr Kochanek, Program wychowania młodzieńca według "Jambów do Seleukosa" Amfilochiusza z Ikonium, Lublin 1985 , maszynopis, s. $110+20$.}

Jest to również praca magisterska napisana w Sekcji Filologil Klasycznej KUL pod kierunkiem ks. doc. dra hab. K. Popowskiego. Całość prezentowanego w niej materiału została ujęta w trzy rozdziały. Pierwszy z nich obejmuje wartości nieakceptowane w procesie chrześcijańskiego wychowania, do których należą: błędy kryjące się w literaturze pogańskiej, obyczaje pogańskie, widowiska teatralne, cyrkowe i hipiczne, herezje oraz księgi niekanoniczne podszywajace się pod miano pism natchnionych. Rozdział drugi przedstawia te wartości, które znajduja akceptację w chrześcijańskim programie wychowawczym, jak pozytywna część wiedzy helleńskiej i pisma ST i NT objęte kanonem oraz ukazuje postać Mojżesza jako wzór dokonywania syntezy pierwiastkc pogańskich z normaili religii objawionej. Wreszcie ostatni trzeci roz. dział stara się określić ldeał wychowania chrześcijańskiego. Ponadto w charakterze aneksów dołączono polski przekład "Jambów do Seleukosa" oraz wykaz zachowanych dzieł Amfilochiusza z Ikonium/ok. 340-396/.

\section{Barbara Poniatowska, Sw. Ambrozy, Pouczenie dziewicy i wie- czne dziewictwo Najświetszej Maryi Panny/Wstę, przekład, komentarz/, Lublin 1987, maszynopis, s. XXV + 56.}

Jest to praca nagistersica pisana w Sekcji Filologii Klasycznej KUL pod kierunkiem ks. doc. dra hab. Henryka Wójtowicza.Przekład "De insticutione virginis" jest pierwszym tłumaczeniem na język polski i jednym z nielicznych w świecie/istnieją tylko trzy tłum. włoskie i jedno hiszpańskie/. Z czterecin dzieł Ambrożego poświęconych dziewic twu /De virginibus", "De virginitate", "Exhortatio virginis"/ "De institutione virginis" powstałe w latach 391-392 stanowi protreptyk do dziewictwa zwalczający błąd Bonozusa, który odrzucał dzłewictwo Maryi "post partum". 